\title{
Leir som varer?
}

\author{
Av Solveig GJesdal
}

Hva skjer egentlig på leir, og har erfaringer fra leir overføringsverdi? Denne refleksjonsartikkelen diskuterer hvorvidt erfaringer konfirmanter gjør på konfirmantleir er avgrenset til leirens fellesskap og rutiner, avgrenset av tid og sted, eller om konfirmanter her gjør erfaringer som de kan ta med seg videre til sin lokale menighet og sin egen hverdag. Jeg gir et innblikk $i$ «leirverdenen» på bakgrunn av observasjon av tre konfirmantleirer og intervjuer med åtte konfirmanter i forbindelse med leirene. Funnene belyses med teori om praksisfellesskap. Artikkelen argumenterer for at leir og fellesskap i lokalmenigheten kan vere det samme praksisfellesskapet, og at leir kan vere med på å føre konfirmanter inn $i$ menighetens fellesskap. Artikkelen bygger på masteravhandlingen Konfirmantleir - en «boble»? (2014) $i$ kirkelig undervisning ved Det teologiske Menighetsfakultet.

Solveig GJeSDAL, f. 1988, Leder i Acta Oppland, 0452 Oslo, E-post: solveig.gjesdal@outlook.com

\section{INNLEDNING}

«Har dere noen tips til hvor jeg bør starte å lese?» Det er en halv time siden alle skulle være i seng, og jeg er med en av lederne for å sjekke at alle jentene er på riktige rom. På runden møtte vi denne jenta. Hun satt i ei av stuene på leirstedet i bare $\mathrm{BH}$ og shorts, og leste i Bibelen. Dette var tredje dag på konfirmantleir, en leirdag som hadde bestått av måltider, undervisning, postløp, verksteder, grilling og kveldssamling. På kveldssamlingen noen timer tidligere var rommet mørkt, og alle satte seg på golvet rundt lyskorset. Først var det lovsang. Konfirmantene sang med blikket festet på lyskorset. Deretter var det andakt og vitnesbyrd, og konfirmantene satt i ro og lyttet, mens noen koste litt med hverandre. Til slutt i kveldssamlingen kunne konfirmantene velge om de ville være i ro, tenne lys, skrive bønnelapper, eller om de ville snakke med eller bli bedt for av en leder. Noen ble sittende og høre på musikken, mens andre tente lys eller skrev bønnelapper, noen ble bedt for, noen gråt og noen trøstet.

Dette skjedde på en av tre konfirmantleirer jeg fikk være med på sommeren 2013. I arbeidet med min masteravhandling fikk jeg et innblikk $\mathrm{i} \ll$ konfirmantleirverdenen». Jeg intervjuet åtte konfirmanter som deltok på disse leirene. De fleste av disse fortalte med stor iver i intervjuene etter leiren om hvordan de hadde hatt det og hva de hadde erfart. At konfirmanter ber, lovsynger, leser i Bibelen, og sier at de føler seg inkludert og at de kan være seg selv - det kan nemlig skje på konfirmantleir. Men er dette noe som varer?

I Den norske kirkes plan for trosopplæring Gud gir - vi deler, begrenses konfirmantleirens varighet. Planen sier dette om konfirmantleirens ramme: «For å ivareta at konfirmasjonstiden gir jevnlig kontakt mellom konfirmanter og menighet, kan ikke leir utgjøre mer enn 50 prosent av konfirmasjonstidens totale omfang» (Top 2010:25). Dette gir uttrykk for en oppfatning av at en lang leir minsker muligheten til jevnlig kontakt mellom konfirmant og menighet. I konfirmantundersøkelsen fra 2008 Confirmation Work in Europe (Schweitzer, Ilg \& Simojoki 2010) kan man se på sammenhengen mellom konfirmantleirens lengde og hvor fornøyd konfirmantene er med konfirmasjonstiden. Her 
kommer det fram at konfirmantenes tilfredsstillelse med konfirmasjonstiden øker med konfirmantleirens lengde (Nimelä 2010:160).

Selv om konfirmantundersøkelsen viser at lang leir har gode effekter, begrenser altså Den norske kirke konfirmantleirens varighet. Har vi grunn til å tro at leir er en arena som er avgrenset fra menigheten - en arena som ikke fører til jevnlig kontakt mellom konfirmant og menighet? I arbeidet med min masteravhandling har jeg jobbet med problemstillingen: «I hvilken grad er konfirmantleir en verden for seg?», og jeg har blant annet hatt som mål å undersøke hvorvidt konfirmantleirenes fellesskap og rutiner har overføringsverdi tilbake til lokalmenigheten.

\section{LITT OM METODENE}

Jeg har gått kvalitativt til verks for å kunne gå i dybden for å forstå mer av hva som skjer på en konfirmantleir. Jeg har brukt to metoder - deltagende observasjon og kvalitative intervjuer. Jeg observerte tre konfirmantleirer fra to menigheter, som alle hadde en varighet på litt under en uke. Menighetene jeg valgte ut hadde en del like kjennetegn, som at de har godt besøkte ungdomsklubber og at de har flere ansatte som jobber med ungdommene. Den deltagende observasjonen besto i at jeg var med på leirene og observerte de ulike programpostene. I fritiden gikk jeg mye rundt for å prøve å få med meg hva som skjedde, og jeg fikk også informasjon gjennom uformelle samtaler med ledere og konfirmanter. De kvalitative intervjuene ble gjennomført med åtte konfirmanter som deltok på leirene, både i starten og i etterkant av leiren. Det første intervjuet hadde som mål å gjøre informanten trygg på meg og på intervjusituasjonen, og å få et innblikk i informantens forventninger til leiren. Intervjuene etter leiren foregikk på ungdomsklubbene. Her var målet å få mer utdypende opplysninger om informantenes erfaringer av å være på leir. I forbindelse med intervjuene etter leiren fikk jeg også noen interessante observasjoner knyttet til menighetenes ungdomsklubber.

\section{LEIR SOM PRAKSISFELLESSKAP}

I masteravhandlingen så jeg konfirmantleirene i lys av blant annet Wengers teori om praksisfellesskap (1998) og Jean Lave og Etienne Wengers (1991) teori om situert læring. Videre forklarer jeg kort hva et praksisfellesskap er, og litt om hvordan Lave \& Wenger (1991) ser på læring i et praksisfellesskap.

Alle fellesskap er ikke praksisfellesskap. For at et fellesskap skal være et praksisfellesskap, skriver Wenger (1998) at de må kjennetegnes av tre dimensjoner: Det må være et gjensidig engasjement, en felles virksomhet og et delt repertoar. Dimensjonen gjensidig engasjement peker på relasjonene og interaksjonen i felles handlinger, og at dette opprettholder praksisfellesskapet. Den andre dimensjonen en felles virksomhet handler om de fortolkninger og reaksjoner som praksisfellesskapet har rundt de aktivitetene som de gjør. Det kan være den forståelsen praksisfellesskapet har av hva som er uviktig og hva som er viktig, og hva man skal si og og ikke si. Et delt repertoar er de ressursene som praksisfellesskapet bruker. Det kan være fortellinger, sanger og rutiner. Praksisfellesskapets repertoar fungerer som felles referansepunkter for de som er med (Wenger 1998).

Læring $\mathrm{i}$ et praksisfellesskap skjer når den som deltar, blir en større del av fellesskapet, og beveger seg inn mot praksisens sentrum. Deltageren kan observere, imitere og etterhvert «absorbere» inn i praksisfellesskapet, og deltageren tar stadig større del i praksisfellesskapets handlinger. Da beveger deltageren seg fra å være en perifer deltager til å bli en sentral aktør. Læring i praksisfellesskapet skjer dermed gjennom deltagelse (Lave \& Wenger 1991). Et eksempel på dette kan være en konfirmant som 
under lystenningen ser at ledere henter seg et lys og sitter i ro med telyset i hendene. Neste kveld imiterer konfirmanten denne handlingen, og etter flere gjentagelser kan et slikt lysrituale bli en mer naturlig og mer meningsfull handling for konfirmanten. Læring i et praksisfellesskap er knyttet til det som skjer i selve praksisfellesskapet, noe som kan gjøre det vanskelig å ta læringen ut av praksisfellesskapet og inn i nye sammenhenger. Når læring er så tett knyttet til praksisfellesskapet - hva skjer da når konfirmanten kommer hjem fra leir? Er det slik at alt som skjedde på leiren forblir på leiren - og at forsvinnende lite blir med hjem?

\section{«LEIRVERDENEN»}

Før jeg drøfter nærmere i hvilken grad leir har overføringsverdi, må vi se litt på hva som karakteriserte disse leirene og fellesskapene som ble dannet der ${ }^{1}$. I intervjuene med informantene fikk jeg et innblikk i konfirmanters tanker og erfaringer etter leir. De fleste sa at leiren ble bedre og morsommere enn forventet og at aktivitetsløypene var det morsomste ved leiren. Alle sa at de hadde blitt kjent med nye, og at de hadde følt seg inkludert på leiren. Noen sa at fellesskapet samlet seg i løpet av leiren - at flere gjenger ble til én. Det informantene sa som hadde negativ vinkling, hadde preg av å være detaljer som at senga var hard. Ingen fortalte om mobbing eller andre alvorlige hendelser. Det kan hende at informantene unnlot å fortelle om negative erfaringer, men også intervjusituasjonen vitnet om at informantene hadde hatt gode leirerfaringer. Informantene fortalte ivrig og nokså ordrikt fra leiren (Gjesdal 2014:55f).

\section{LEIRFELLESSKAPET}

Leirfellesskapet ble blant annet beskrevet som et fellesskap der man kunne være seg selv, et felles- skap der man kunne snakke om alt, og et fellesskap med samhold. På kveldssamlingene på alle leirene hadde unge ledere andakter eller vitnesbyrd der de fortalte noe fra sitt liv som på en eller annen måte relaterte til livet med Gud. Noen av disse fortellingene var veldig sterke og ærlige, og vitnet om at flere i ungdomsmiljøene hadde mye i bagasjen. Da jeg spurte en informant om hvordan dette påvirket fellesskapet på leiren, sa han dette: «Det knytter seg mer sammen. Føler mer tillit. Folk er helt åpne mot hverandre» (Gjesdal 2014:50). Andre sa også at man kunne snakke om alt i fellesskapet. Det virker som at det skjedde en «mester-lærling-effekt» da lederne fortalte slike historier. Ungdomslederne ble forbilder, og det ble sendt signaler om at man kan dele det man vil i fellesskapet. Etter hvert vil kanskje konfirmantene imitere dette, og på den måten bli mer sentrale aktører i praksisfellesskapet. Det er ikke nødvendigvis problemfritt at private og tunge livsfortellinger blir fortalt foran alle, men det virker som at informanter syntes dette var positivt.

På noen måter kan fellesskapet som ble dannet på konfirmantleirene sammenlignes med det kristne fellesskapet på urkirkens tid. Flere av ungdomslederne snakket om fellesskapet som en familie. Sandnes (1994) skriver om flere kjennetegn ved de tidlige kristne fellesskapene, at da de kristne delte tid, delte de også etter hvert ressurser og omsorg. I urkirkens tid ble det kristne fellesskapet omtalt som en familie, men da som en annerledes familie enn det som var vanlig. I den kristne familien var alle inkludert uavhengig av rang og kjønn. På konfirmantleirene var det også ulik status blant konfirmanter og ledere, kanskje spesielt med tanke på sosial status. Likevel sa flere at alle ble en gjeng, noe også jeg observerte. Omsorg ble vist konfirmantene imellom, og også på tvers av rollene som ledere eller konfirmanter. Mest synlig var dette da del-

1 I denne artikkelen skiller jeg ikke mellom de tre leirene, da alle leirene var nokså like på de områdene som blir tematisert her. 
tagerne trøstet hverandre på kveldssamlingene. Ei av lederne fortalte i en andakt på en kveldssamling at da hun ble en del av fellesskapet på ungdomsklubben, var det uvant for henne å bli spurt om hvordan hun hadde det. Jeg tror dette er med på å vise at omsorgen i fellesskapet er mer enn trøst på følelsesladede kveldssamlinger, men at fellesskapet mer grunnleggende kjennetegnes av at man bryr seg om hverandre.

Det var flere som nevnte at man kunne være seg selv på leiren. Ei sa dette da jeg spurte hvordan hun ville beskrive leirens miljø: «Veldig bra! Veldig hyggelig, og alle var jo ... Det var jo ikke noe drittslenging, som jeg fikk med meg hvertfall! Man kunne være seg selv» (Gjesdal 2014:49). Ei annen sa at hun erfarte at det ikke var noe konkurranseinstinkt på leiren, og at det ikke var om å gjøre å være best slik hun var vant til i en fritidsaktivitet hun brukte mye tid på. Vi vet at ungdom også har en hverdag preget av mye konkurranse og vurdering gjennom skolen (Skaalvik \& Skaalvik 2013). Det virker som at denne jenta erfarte et pusterom på leir fra en prestasjonspreget hverdag.

Selv om leirfellesskapene hadde mange gode kvaliteter, og flere i intervjumaterialet sier at de kunne være seg selv, og at ei sa at det ikke var noe konkurranseinstinkt, så var det noe som brøt med dette. To av leirene inneholdt en prøve, mens den siste leiren hadde en gallamiddag. En informant fortalte at hun syntes gallamiddagen ga et slitsomt fokus på utseende. Både prøven og gallamiddagen bringer inn elementer som bryter med idealene som ellers gjennomsyret leirene. Prøven bringer inn et skoleelement som mange har negative assosiasjoner til, og gallamiddagen kan lett føre til sammenligning og et negativt kroppsfokus. Helhetsinntrykket fra intervjuene og observasjonen fra leirene gjør at jeg likevel tror at disse elementene ikke ødela altfor mye, men det er viktig å være oppmerksom på hva slags aktiviteter og elementer man tar inn i leiren, og vurdere om disse går overens med det man ønsker å formidle (Gjesdal 2014:59f).

\section{LEIRRUTINER}

Alle leirene hadde et ganske fast mønster for hvordan dagsprogrammet så ut. Det var en del like tidspunkter, og gjentagelse av de samme programpostene fra dag til dag. Det var faste tider for måltidene, for undervisning, aktiviteter, underholdning og kveldssamlinger. Ikke bare det - men innenfor flere av programpostene var det også et sett med rutiner som ble fulgt fra dag til dag. Det var spesielt kveldssamlingene som fanget min oppmerksomhet. Opplegget på kveldssamlingene hadde en nokså fast rekkefølge som gjentok seg hver kveld, omtrent slik jeg skisserte innledningsvis.

Kveldssamlingen inneholder flere kristne praksiser $^{2}$ - lovsang, bønn, lystenning, og vitnesbyrd eller andakt. Siden disse praksisene ble gjentatt hver kveld, og gjentatt i stort sett samme rekkefølge, ble denne kveldssamlingen etter hvert en rutine for konfirmantene. Praksisene ble mer og mer kjente, og det virket som at det ble lettere og vanligere for konfirmantene å delta. Kveldssamlingen ble en rutine, og en del av praksisfellesskapets delte repertoar. Slik som det å vise at man kunne dele alt, ble en forbildehandling, ble også kveldssamlingen og dens kristne praksiser handlinger som konfirmanter kunne se, imitere og gjøre til sine egne. Gjennom økt deltagelse på kveldssamlingene kunne konfirmantene bevege seg fra å være perifere deltagere i praksisfellesskapet til å bli mer sentrale aktører.

At leiren er bygd opp av repeterende mønstre og rutiner, er noe som fører til forutsigbar-

2 Eksempler på kristne praksiser kan være bønn, Guds ord, nattverd og tjeneste. Også lystenning, lovsang og vitnesbyrd defineres innenfor kristne praksiser. Hallesby Norheim skriver om kristne praksiser i Kan tru praktiserast (2008). 
het og oversikt, og som gjør at det blir lettere å delta i leiren. En informant sa at han ble tryggere på leirens andre dag, etter at han hadde hørt om programmet og fått vite om «ditt og datt» (Gjesdal, 2014:65). Dette med at struktur fører til trygghet er noe som Skaalvik \& Skaalvik (2013) belyser. Behovet for struktur kan variere ut ifra modenhet og alder, men det er også noe alle trenger. Skaalvik \& Skaalvik skriver at struktur gjennom eksempelvis tydelige forventninger, regler og framgangsmåter er med på å skape forutsigbarhet og en trygg ramme å utfolde seg innenfor. Spesielt en av leirene hadde potensiale til å lage mer forutsigbare rammer, med tanke på å følge oppsatte tidspunkter og ha tydelige og håndhevede regler.

Det er mange koder på leir som kan skape usikkerhet dersom det ikke informeres tilstrekkelig før det gjennomføres. Det gjelder de kristne praksisene, men også ting det er lett å tenke at deltagerne vil skjønne underveis. Det er ikke alle deltagere som vet at man skal vente til etter et bordvers med å spise, eller som vet hva bjelleringinga betyr. At kodene eller praksisene blir gjentatt en eller flere ganger hver dag, og at de andre lederne allerede følger disse, gjør at deltagerne selv vil skjønne logikken etter hvert. Likevel tror jeg det er lurt å reflektere rundt om det er noen koder og kristne praksiser på leiren som man kunne informert mer om. Da kunne deltagere som ikke har vært på denne type leir før, føle seg trygge enda tidligere, og de kristne praksisene kunne blitt informerte ${ }^{3}$ og mer meningsfulle for deltageren.

\section{HAR FELLESSKAPET OG RUTINENE OVERFØRINGSVERDI?}

Inne i disse «leirverdenene» befant det seg altså et sett med rutiner, og det ble dannet fellesskap som virker annerledes enn de som ungdom til daglig tilhører. Men er leirfellesskapene og leirrutinene noe som bare skjer i leirens tid og sted, eller er dette noe som blir med hjem? Disse to menighetene hadde hver sine ungdomsklubber med en del likheter fra klubb til leir. I arbeidet med avhandlingens analyse hadde jeg lenge en tanke om ungdomsklubben og leiren måtte være to ulike praksisfellesskap. I Communities of practice (1998) skriver Wenger om forbindelser mellom praksisfellesskap, forbindelser i form av grenseobjekter og forhandlere. Jeg så for meg at ungdomslederne på konfirmantleirene kunne være slike forhandlere, som tar med seg elementer fra ungdomsklubben og overfører det til leiren. Men ifølge Wenger er slike forhandlere perifere i begge fellesskap. Det vil si at forhandlerne beveger seg i praksisfellesskapets utkant, uten å være i praksisens midte. Det kunne jeg umulig se for meg at kunne stemme for ungdomslederne, som så ut til å «eie» både ungdomsklubben og leiren. Jeg skjønte også etter hvert at kveldssamlingen ikke bare ble gjennomført på leir, men den var en fast og viktig del av begge menigheters ungdomsklubber. Navnet på begge menigheters kveldssamling var godt innarbeidet, og det var samme rutine på leir som på ungdomsklubbene. Disse oppdagelsene gjorde at jeg begynte å undersøke om leir og klubb kunne være ett og samme praksisfellesskap. Dette ville i så fall bety at å bli en del av fellesskapet på leiren også kan oppleves som å bli en del av ungdomsklubbens fellesskap - som jo er en del av lokalmenighetens fellesskap.

Jeg så derfor på om Wengers tre dimensjoner ved praksisfellesskapet var de samme både på klubb og på leir. Et gjensidig engasjement kan være det samme på leir som på klubb ved at relasjonene som ble dannet på leiren, kan føres videre på ungdomsklubben. Før leiren startet, eksisterte det allerede relasjoner som opprettholdt fellesskapet, ved at fjorårskonfirmantene

3 Heid Leganger-Krogstad bruker begrepet informert praksis om det å forstå meningen og hensikten ved praksisene i trosopplæringen (Leganger-Krogstad 2008) 
og de av konfirmantene som hadde deltatt på ungdomsklubben, var knyttet til de andre lederne og ansatte. I tillegg merket jeg at konfirmantene og lederne snakket om fellesskapet på leir ved samme navn som ungdomsklubbenes navn. Dermed virket det som at deltagerne oppfattet både leiren og ungdomsklubben som det samme fellesskapet. En delt virksomhet som var lik mellom leir og klubb, kan være kveldssamlingen. Kveldssamlingen ble så og si likt gjennomført og håndtert av deltagerne på leiren som på menighetens ungdomsklubb. Den siste dimensjonen, et delt repertoar, kunne man blant annet se i innholdet i kveldssamlingen. Det var de samme kristne praksisene i kveldssamlingen på leir og på klubb, for eksempel de samme sangene og samme måte å tenne lys på (Gjesdal 2014:69f).

Disse koblingene som konfirmanter kan erfare mellom leir og klubb, gjør at jeg mener at konfirmantene på disse tre konfirmantleirene føres inn i menighetens lokale fellesskap gjennom deltagelse på leiren. Fellesskapet og flere av de samme rutinene blir med hjem til ungdomsklubben. Likevel er leir en helt annerledes situasjon enn den man møter på menighetens ungdomsklubb eller gudstjenester. Jeg tror det er tidsaspektet ved leir som gjør at praksisfellesskapet endrer karakter på leir. På leir er de samme menneskene samlet over lang tid, og man rekker å bli trygg på hverandre og trygg på det man gjør. På en klubbkveld vil sammensetningen av mennesker være forskjellig fra uke til uke. Informanter sa at på ungdomsklubben er man mer med de man allerede kjenner fra før. Informanter påpekte også at kveldssamlingen på leir var mer koselig og intim enn den er på ungdomsklubben.

Praksisfellesskapet vil kanskje ikke erfares som like tett etter leiren, men mange av de samme menneskene og noen av rutinene blir med tilbake til menighetene. Når kveldssamlingen gjennomføres likt på ungdomsklub- ben, gjennomføres også de kristne praksisene. Mange av konfirmantene har fått erfaring med disse, og gjennom konfirmantenes deltagelse kan de kristne praksisene bli mer meningsfulle. På denne måten kan det hende flere beveger seg mot å bli mer sentrale aktører i praksisfellesskapet. En informant fortalte at han ikke trengte å gå i kirka for å be, siden han kunne gjøre det hjemme. Også flere fortalte at de har bedt etter leiren, noe som kan bety at de kristne praksisene kan bli med helt hjem etter leir, ikke bare til ungdomsklubben.

Overgangen fra leir til hverdag kan by på utfordringer, og jeg erfarte at dette ble reflektert over blant de ansvarlige for leirene. På alle tre leirer snakket enten presten eller kateketen til konfirmantene om denne overgangen, om at ikke alltid familien forstår hvordan det er å være på leir og det man kan ha opplevd der. Det ble også informert om en klubbkveld med mimring fra leir med bilder og film, der konfirmantene ble spesielt invitert, og konfirmantene fikk mulighet til å melde seg på lederkurs. På to av leirene var det avslutningsgudstjeneste og kirkekaffe der foresatte og familie var invitert. Dette er tiltak som kan gjøre overgangen fra leir til hverdagsliv, familieliv og menighetsliv lettere. Det er viktig at ansvarlige for leirarbeid tar tak i utfordringene ved overgangen fra leir til hverdagsliv.

Jeg spurte informantene mine om de hadde fått lyst til å delta mer i fellesskapet etter leiren, og der svarte alle ja utenom en. Da jeg spurte om de hadde fått mer lyst til å delta i kirken etter leiren, var de ikke like positive. Det tyder på at disse menighetene har en utfordring når det gjelder å knytte konfirmantleiren ikke bare til ungdomsklubben, men også til gudstjenestelivet. Jeg tror at konfirmanter som har hatt såpass gode erfaringer som det virker som at mine informanter har hatt, vil få gode assosiasjoner til kirken og kristendommen senere i livet. Det er kanskje jenta som sa dette et eksempel på: 
- Har du erfart noe nytt?

Ikke no annet enn å bli kristen. $\mathrm{Og}$ møte nye mennesker og få nye venner

- Er det noe som har forandra seg etter at du har vært på leir?

Jeg har lest mer i den derre boka vi fikk. «Bønn», «En litt annerledes bibel» eller no sånn. Også har jeg bedt.

- Hva tror du denne leiren kommer til å bety for deg?

Det er noe av det ... Hvis folk snakker om det så sier jeg, det er det beste jeg noen gang har vært på. Jeg synes det var så koselig å ... Alt var bare gøy, det var liksom ingenting som var dårlig, som jeg synes. $\mathrm{Og}$ at det var en opplevelse for livet, og at jeg kommer til å huske det for alltid.

Jeg tror at konfirmanter som har erfart en god konfirmantleir, ønsker å fortsette i fellesskapet og oppsøke ungdomsklubben eller kirken senere i livet i større grad enn de som ikke har hatt en slik erfaring. Om konfirmantleiren ikke skulle føre til noen umiddelbar deltagelse på klubb eller gudstjeneste, har jeg likevel tro på leirens egenverdi. Mer tradisjonelle konfirmanttimer vil trolig ha vanskelig for å få til samme fellesskapsfølelse og engasjement som en leir kan skape.

\section{AVSLUTNING}

Det skjer mye verdifullt inne i «leirverdenene». Noen erfarte at de kunne snakke om alt, noen at de kunne være seg selv, mange sa de ble inkludert, og ei fortalte om et pusterom fra en prestasjonspreget hverdag. Flere fortalte også at leiren hadde preget troen deres. På leir gjentas leirrutinene fra dag til dag, relasjoner etableres og utvikles, og til slutt ser det ut som at alle har blitt en stor gjeng. Etter leirene fortsetter ungdomsklubbene, med samme kveldssamling og med de samme kristne praksisene. Dersom konfirmantene blir med på ungdomsklubben, er det dermed mulig for konfirmantene å bli mer sentrale aktører i praksisfellesskapet også etter leiren. Likevel er leir et annerledesland. Leirkvelden jeg skisserte innledningsvis med lovsang og grining på kveldssamling, og bibellesing i $\mathrm{BH}$, kan nok virke fjern fra hverdagslivet. Det er vanskelig å ta med seg alt fra leiren hjem, kanskje spesielt den samme stemningen og fellesskapsfølelsen som flere snakket om.

Det virker som at de menighetene jeg har besøkt, har lykkes i å skape et helhetlig ungdomsfellesskap som knytter sammen konfirmantene til resten av menighetenes ungdomsarbeid. Det er ikke slik i alle menigheter. Det er en stor og viktig utfordring å knytte konfirmantleiren eller andre leirer opp til lokale fellesskap, slik at leir ikke får en brå slutt siste dag på leir. Når man tilrettelegger for leir, bør man jobbe bevisst for at erfaringer som gjøres på leir, kan peke utover selve leiren, og legge til rette for at leiren skaper forbindelser til ungdommenes egne liv og til menighetenes aktiviteter og gudstjenester. Når konfirmanter sier de har lyst til å delta i fellesskapet etter leir, må vi i den grad det er mulig, legge til rette for at dette kan skje. Leiren varer kanskje ikke mer enn ei uke, men den kan være en inngangsport til det lokale menighetslivet og gi erfaringer for livet.

\section{LITTERATUR}

Den norske kirke. 2010. Gud gir - vi deler: plan for trosopplcering i Den norske kirke. Oslo: Kirkerådet.

Gjesdal, Solveig. 2014. Konfirmantleir - en «boble»? (Masteravhandling, Det teologiske Menighetsfakultet), Solveig Gjesdal, Oslo.

Hallesby Norheim, Bård Eirik. 2008. Kan tru praktiserast? Teologi for kristent ungdomsar- 
beid. Trondheim: Tapir Akademisk Forlag. Leganger-Krogstad, Heid. 2008. Smake og kjenne. Lys og Liv, 4 s. 16-17

Lave, Jean \& Wenger, Etienne. 1991. Situated Learning: Legitimate Peripheral Participation. Cambridge: Cambridge University Press.

Niemelä, Kati. 2010. «Positiva och negativa upplevelser av konfirmandtiden». I Bernd Krupka, \& Ingrid Reite (red.), Mellom pietisme og pluralitet. Konfirmasjonsarbeid i fire nordiske land (s. 152-167). Oslo: IKOForlaget.

Sandnes, Karl Olav. 1994. Menigheten - Guds familie og våre søsken: det kristne fellesskapet som utfordring. Oslo: Credo Forlag.
Schweitzer, Friedrich, Ilg, Wolfgang \& Simojoki, Henrik. 2010. Confirmation Work In Europe: Empirical Results, Experiences and Challenges. A Comparative Study in Seven Countries. Güttersloh: Gütersloher Verlagshaus.

Skaalvik, Einar M. \& Skaalvik, Sidsel. [2005] 2013. Skolen som leringsarena: Selvoppfatning, motivasjon og lering. Oslo: Universitetsforlaget.

Wenger, Etienne. 1998. Communities of practice: Learning, Meaning, and Identity. Cambridge: Cambridge University Press. 